\title{
QUIET STUDY AREA: No applause
}

\section{between movements}

\author{
By Bonnie Biggs \\ Coordinator of Library Services \\ San Diego State University, North County \\ and Assistant to the Director for Library Services \\ California State University, San Marcos
}

\section{The concert series at San Diego State University, North}

\section{County, is not "weird." Is it "unusual"?}

ince the winter of 1987 , our small satellite campus library has doubled as a concert hall for over 100 musicians. Artists who enjoy international acclaim and frequent bookings at Carnegie Hall and Lincoln Center have also enjoyed performing in our makeshift auditorium, located in an industrial park in San Marcos, California, population: 33,000 .

The history of a concert series that would not die is tied closely to the history of a university that would not die. That university, California State University at San Marcos, is the only new university being built in the country today. But before that, we answered to a different, temporary name.

After ten years of efforts to interest state, educational, political, and fiscal leaders in the development of a state university in the area, San Diego State University opened a satellite campus in northern San Diego County in 1979. The center was needed to alleviate the congestion on the main campus $(32,000$ students $)$ and to meet the growing demand for higher education in the area. By 1986, when I came on board as coordinator of library services, our student population was 967 (360 FTE) and growing by $10 \%$ each semester. We offered 93 upper division and graduate courses, and the library occupied a small classroom of about 1,200 square feet, housing a modest collection of 3,800 volumes.
When Dr. Richard R. Rush, director of the North County campus, hired me, he noted that my public library background was rich with experience in coordinating concerts and jazz festivals. I was charged with the responsibility to establish a tradition of cultural events at the fledgling university. This was in addition to a myriad of other, more traditional tasks including collection development, planning for bibliographic instruction and reference services, coordinating three library expansions, and hiring additional staff.

The university's presence in the community was still a well-kept secret, and it was my guess that by providing the surrounding eight small communities with a reason to come to us, we would begin to establish an identity. Public relations, though generally considered public library turf, turned out to be an essential tool in spreading the word about the North County campus and contributing to our rapid growth.

We decided to call our inaugural event a "Twelfth Night" concert since it was held in early January. We also decided to put out literature on the formation of a friends group on the night of the concert and to provide refreshments at the same table. We invited a quintet of principal brass players from the San Diego Symphony to perform, and they graciously accepted. I must confess that having a spouse who is a noted string bassist in both the 
jazz and classical worlds is an advantage when it comes to musical contacts. However, one can always contact the local musician's union, jazz society or symphony orchestra business office for referrals.

On a cold, rainy night in early January, our tiny library was crammed to capacity with people from all over San Diego County, including several civic leaders. The concert was a huge success. We received extensive press coverage, 16 people signed up for the friends group, a mailing list was initiated, and we were on our way.

Sponsoring a jazz concert next was a natural, given the contacts built into our circle of friends and given the fact that the bassist would perform gratis! Because a course on jazz was offered that semester, we were able to receive Instructionally Related Activities (IRA) funds for the concert, and students enrolled in the jazz course were required to attend. The featured artist, guitarist Peter Sprague (Discovery label), was likely to draw a crowd larger than the library could handle, so an outdoor Saturday concert was planned. Chairs had to be borrowed from the city, and details for roping off the lot had to be worked out with campus safety officials. We publicized in over 10 local newspapers as well as two jazz radio stations and sent out 1,000 flyers.
The concert drew 350. Several people commented that they didn't know we existed before they heard about the concert, something we would continue to hear for the next several years. The concerts gave us a unique visibility that conventional university outreach did not.

For our next concert, we piggy-backed on a rare San Diego engagement featuring the legendary blues singer, Mose Allison. We were able to secure corporate funding from Pacific Bell for this special event. Naturally, our flyers, posters, and press releases indicated the funding source, an important detail. This time chairs were borrowed from a local public library, and the sound system came from a nearby community college. The library had doubled in size during the summer, so we decided to hold the performance inside and increased our publicity efforts. Two local newspapers did feature articles and interviews with Mose. A great deal of excitement preceded the concert. People were amazed that Mose Allison would come to San Marcos! San Marcos is 40 miles north of San Diego in an area that, until recently, was primarily rural. Some would call it a cultural wasteland, but we were committed to changing that image. The concert drew close to 500 people from three neighboring counties and literally put us on the map!

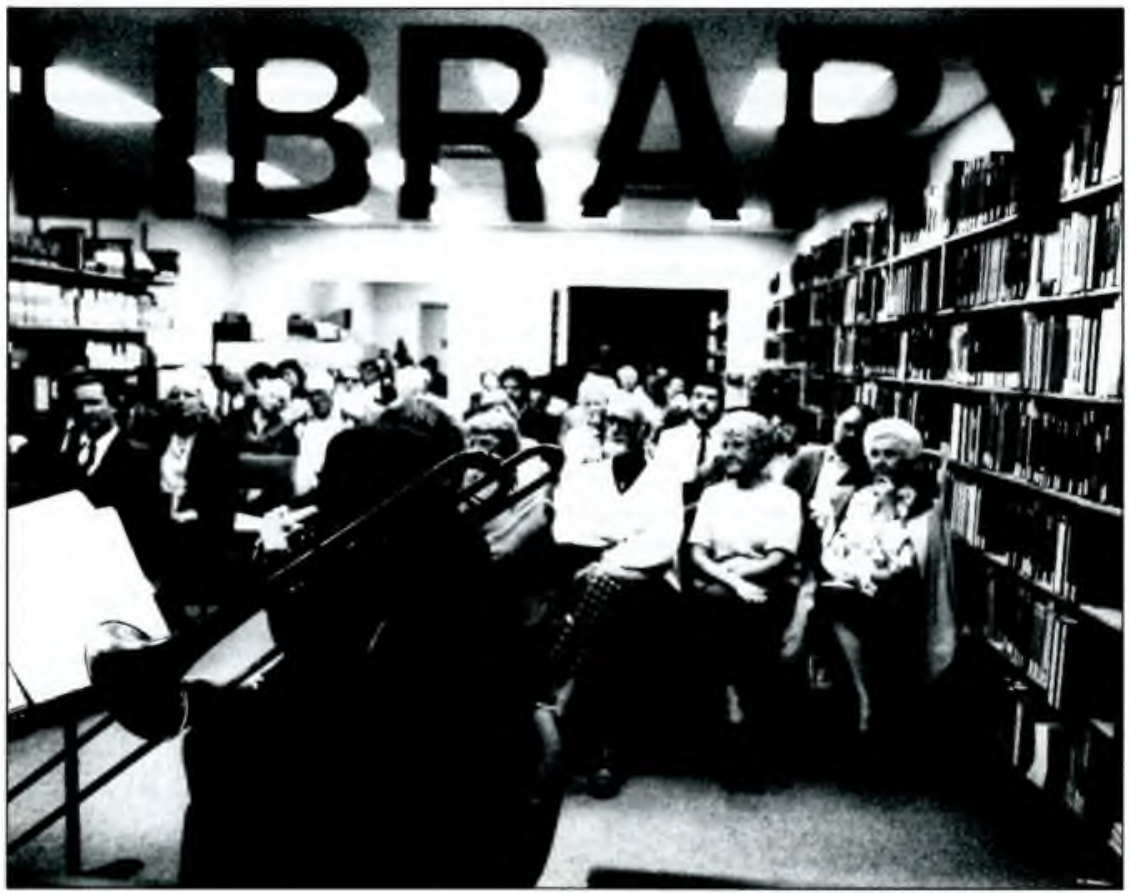

Photo by Robert Gauthier, Times Advocate 
After this astonishing success, the administration was sold on having regular concerts, but securing regular funding for such a series would present a problem. The answer to the funding problem fell into our laps that following summer. We began offering a course called Music in Contemporary Life which incorporates a requirement to attend a certain number of live concerts per semester. The San Diego campus offers concerts through Associated Students' funding, and students get a break on admission. Because our student council was one semester old with a bank account to match, we needed to look for alternate sources of funding. We discovered we could qualify for state lottery funding under the lottery fund allocation category called Distinguished Visiting Scholars and Artists. Thus began the Sunday Evening Concert Series that continues to grow in popularity with the campus community, now 2,500 (1,017 FTE) students, as well as with the community at large.

Highlights of our series have included an appearance by bebop alto saxophonist Charles $\mathrm{McPherson}$, which coincided with the release of Clint Eastwood's movie Bird, in which McPherson doubles for Charlie Parker on the soundtrack. For Black History Month we invited a 100-voice gospel choir from the inner city and had to borrow a civic facility for the event. We have had an Indonesian gamelan group, the Andean group, Sukay, several classical chamber groups, opera soloists, and an avant garde ensemble combining music with performance art. Mike Wofford, pianist for Ella Fitzgerald, played for a standing room only crowd. We have been very careful to keep the quality of performers at an extremely high level. This one factor alone has distinguished our series from other local fare.

To support course objectives, we schedule concerts featuring the musics being studied. Every semester includes a classical, a jazz, and an ethnic music concert. The performers are contracted to do the concert on a Sunday evening and meet with the music class the following Monday morning to discuss the performance and answer students' questions. The students enrolled in the class, in lieu of paying for concerts, help set up the "concert hall" in the library, which entails moving reading carrels and other furniture, setting up 300 or more chairs and passing out programs. Over 3,000 flyers and posters are produced and distributed. Student organizations sell refreshments at the concerts and enjoy a nice profit.

No admission can be charged when using lottery funds, and because student attendance is required for educational purposes, we are exempt from any American Society of Composers, Authors and Publishers (ASCAP) licensing demands. ${ }^{1}$

${ }^{\text {I}}$ Robert A. Wynbrandt, “Musical Performances
The logistics inherent in a six-concert semester are complex. The coordination of publicity is time intensive, but because we do not have a built-in campus community, we have learned to overdo publicity and have enjoyed tremendous visibility as a result. Setting up the "concert hall" requires the effort of all library staff (all three of us!), goodnatured spouses, and students enrolled in the music classes, under the direction of a dedicated music instructor.

A nice offshoot of the publicity effort is the "Rogue's Gallery" of $8 \leftrightarrow 10$ black and white photos of all the artists who have performed in the library. This photographic display graces the tops of our microfiche cabinets and draws considerable attention. After the library expanded again, our mother campus donated a six foot Steinway grand piano. We have also acquired 400 stackable chairs and a professional quality sound system.

In addition to the concert series, we have sponsored three enormously popular American Indian storytellings, a Mexican fiesta, and a Friday Evening Speakers Series, and we recently initiated a noontime brown bag concert series. The library staff is a small but mighty one that, while intensely involved with the conventional development of the library collection and services, has never lost sight of the "bigger picture." Our cultural events fall under the category Sherman Hayes would call "weird and/or unusual" activities. ${ }^{2}$ Although the events cannot be considered core services by any means, they have drawn considerable attention to the library and have captured the attention of ethnic groups, seniors and others who might otherwise have gone untouched by the university.

\section{Rewards}

On the evening of our inaugural concert, Dr. Rush, now executive vice president of CSU San Marcos, greeted the crowd with the comment: "Now I KNOW that this has become a university because we now have the arts." That started a chain of events, responses and moments that have rewarded our hard work a thousand times over. Bringing world-class musical artists to this emerging region has helped us to establish a reputation with the campus, the public, and library communities in southem California. We are held in high regard by the performers, who always receive fair compensation, extensive publicity, respect, sparkling water, and home baked goodies in their

in Libraries: Is a License from ASCAP Required?" College \& Research Libraries News 51 (May 1990): 404-06.

${ }^{2}$ Sherman Hayes, "Wanted: Weird and/or Unusual Services and Activities," College \& Research Libraries News 51 (April 1990): 322-25. 
"dressing rooms." Probably the greatest joy is in knowing that the concerts draw hundreds of people who might never visit an academic (or any!) library and who certainly would never enter a jazz club or perhaps wouldn't make the drive 40 miles south to Symphony Hall. So often, these "strangers" leave the library uplifted by the music and enchanted by the place that hosted it. They often return, and remain, friends for life.

San Diego State University, North County, will "phase down" its operation over the next two years as we become a part of the twentieth California State University. In 1992, California State University, San Marcos, will abandon its industrial park quarters and move to a 304-acre site nearby. The library will initially occupy two floors of a five-story administrative building, and expects to open its doors in 1992 with a collection of 50,000 volumes. The permanent library and the performing arts building are scheduled for the second phase of construction.

The mission statements for the library, the Friends of the Library, and the university all commit to providing a forum for the arts. We look forward to the construction of a full-service, 21 stcentury performing arts center, but as the library's mission statement reads, we will continue "to serve as a cultural center for the campus and the local community." Why not?

\section{C\&RL News guidelines for}

\section{submission of articles or columns}

\section{A statement of purpose and content for College \& Research}

\section{Libraries News.}

\section{Purpose of CbRL News}

College \& Research Libraries News is the official news magazine of the Association of College \& Research Libraries, a division of the American Library Association, it reflects the priorities of ACRL as embodied in the goals and objectives of its Strategic Plan. Its purpose is to record significant activities of ACRL and to report news about academic and research libraries. As the official ACRL news magazine, C\&RL News maintains a record of selected actions and policy statements of the Association and publishes timely reports on the activities of ACRL and its sections, committees, discussion groups, councils, task forces, and chapters.

As a vehicle for communication among college and research libraries, C $b R L$ News reports news items pertinent to academic and research librarianship, including information on bibliographic instruction, continuing education, appointments, acquisition of special collections, grants to libraries, new technology. and publications (brief notices).

The editor bears responsibility for the contents of each issue of $C \downarrow R L$ News. Materials selected by the editor must be newsworthy, timely, and of practical value to people in the field. The editor has authority to decide what material is appropriate for publication, based on the following guidelines. The editor also reserves the right to make appropriate revisions in material selected for publication in order to standardize style or improve clarity (except official ACRL documents, president's letters, and similar material).

Formal, theoretical, or research-oriented articles inappropriate for $C \& R L$ News will be forwarded to the editor of College $\&$ Research Libraries for review.

\section{Length}

Articles and columns should be no more than 3,000 words and no less than 500 words.

\section{Style}

$C \& R L$ News style is informal, but informative and accurate.

\section{Content}

Materials selected should fall into one of the following categories. 